\title{
THE CONVERSION OF N - METHYLANILINE AND N -, 2 - DIMETHYLANILINE BY USING DIFFERENT CATALYSTS
}

\author{
Aghayev Akbar Ali ${ }^{1}$, Musfatayeva Naila Abdulla ${ }^{2}$, Shahtakhtinskaya Pari Turabkhan ${ }^{3}$, \\ Muradov Mahal Mayil ${ }^{4}$, Nasirova Irada Mammad ${ }^{5}$ \\ ${ }^{1}$ Doctor of Chemical Sciences, Professor, the Head of the Department of "Petrochemistry and Chemical \\ Technologies", Sumgait State University, Sumgait, Azerbaijan \\ irapon.sdu@mail.ru \\ ${ }^{2}$ Lead Teacher of the Department of "Chemistry of High Molecular Compounds and Analytical Chemistry", \\ Sumgait State University, Sumgait, Azerbaijan \\ naila550@mail.ru \\ ${ }^{3}$ Associate Professor of the Department of "Petroleum Chemistry and Chemical Technologies", Sumgait State \\ University, Sumgait, Azerbaijan \\ ${ }^{4}$ Associate Professor of the Department of "Petroleum Chemistry and Chemical Technologies", Sumgait State \\ University, Sumgait, Azerbaijan \\ mailoglu@mail.ru \\ ${ }^{5}$ Lead Teacher of the Department of "Petroleum Chemistry and Chemical Technologies", Sumgait State \\ University, Sumgait, Azerbaijan
} ABSTRACT

The catalytic conversion of $\mathrm{N}$ - methylaniline and $\mathrm{N}-, 2$ - dimethylaniline in the presence of $\mathrm{Pd}-\mathrm{HSHM}$, $\mathrm{CuFe}_{2} \mathrm{O}_{4} \cdot \mathrm{V} \cdot \mathrm{Al}_{2} \mathrm{O}_{3}$ and vanadium - chromium - aluminium (VChA) oxide systems has been investigated. The comparative analysis of the results of the conversion of three different feedstocks with VChA catalyst shows that the xylidines, especially 2,6 - dimethylaniline is formed as a result of the methylation of aromatic amine because of the carbon in nucleus.

\section{Indexing terms/Keywords}

2 - methylaniline, methanol, N-, 2 - dimethylaniline, 2,6 - dimethylaniline, xylidines, catalyst, N-alkylation, C -alkylation

\section{Academic Discipline And Sub-Disciplines}

Chemistry

\section{SUBJECT CLASSIFICATION}

Chemical Technologies

\section{TYPE (METHOD/APPROACH)}

Experimental

\section{INTRODUCTION}

The researches of the previous years prove that alkylates which is formed as a result of the reaction of aniline and 2 - methylaniline with methanol contain alkylation products due to carbon and nitrogen. Their presence, concentrations and yields vary depending on the composition of catalyst and reaction medium. A group of researchers (1, 2) claim that the alkylation products due to nitrogen, as well as $\mathrm{N}$ - methyl amines act as intermediates in the synthesis of toluidine and xylidine. According to the opinion of the other researchers $(3,4)$, the alkylation of aniline and toluidine with methanol due to carbon dominates during the production of toluidines and xylidines.

\section{EXPERIMENTALS}

First, the catalytic properties of three catalysts in the alkylation reaction of aniline and 2 - methylaniline with methanol have been studied. These catalysts are $\mathrm{Pd}-\mathrm{HSHM}, \mathrm{CuFe} \mathrm{O}_{4} \cdot \mathrm{\gamma} \cdot \mathrm{Al}_{2} \mathrm{O}_{3}$ and vanadium - chromium - aluminium (VChA) oxide systems.

The researches have been conducted in the continuous reactor and the volume of the immovable layer catalyst was $10 \mathrm{~cm}^{3}$. The products were analyzed with chromatographic and spectral methods (5-7). The results of the conversions of $\mathrm{N}$ - methylaniline and $\mathrm{N}-, 2$ - dimethylaniline in the presence of these catalysts are given in table 1 and 2 . Their evaluations show that all of these catalysts are able to convert $\mathrm{N}-$ methylaniline and $\mathrm{N}-, 2$ - dimethylaniline deeply. Pd HSHM catalyst, which converts them $98-100 \%$, produces complex mixture of toluidine and xylidine. More $\mathrm{m}$ - and $\mathrm{p}$ isomers are formed as a result of the conversion of both $\mathrm{N}$ - methyl amine. 3- and 4- methylanilines are formed when $\mathrm{N}$ methylaniline is used and 2,4- , 2,5- and 2,3- dimethylanilines are formed when N-, 2 - dimethylaniline is used. The total selectivity of these isomers of produced isomers is $44 \%$, however the total selectivity of the mentioned isomer mixture of xylidines is $48 \%$. 


\section{RESULTS AND DISCUSSIONS}

Copper/iron catalyst shows high selectivity in o-isomer production. 2 - methyl aniline is formed with $52.5 \%$ selectivity from conversion of $\mathrm{N}$ - methylaniline whereas 2,6 - dimethylaniline is formed with $53.0 \%$ selectivity from conversion of $\mathrm{N}-, 2$ - dimethylaniline. The rest of them is the other isomers of toluidine and xylidines, respectively. It should be mentioned that the conversion of $\mathrm{N}$ - methylamines is low $(87.0-88.5 \%)$ in the presence of $\mathrm{CuFe}_{2} \mathrm{O}_{4} \cdot \mathrm{Y}^{\cdot} \cdot \mathrm{Al}_{2} \mathrm{O}_{3}$.

Among the used catalysts, VChA oxide system has unique catalytic property. The mole ratio of orto isomers (2 methylaniline and 2, 6 - dimethylaniline) which is formed as a result of the isomerization of $\mathrm{N}-$ methylaniline and $\mathrm{N}-, 2-$ dimethylaniline in the presence of this catalyst, to the other isomers of toluidine and xylidine is $1: 1$.

The next stage of the research has been conducted in the presence of VChA catalyst.

Table 1. The results of the conversion of $\mathbf{N}$ - methylaniline with different catalysts. Reaction conditions: $\mathrm{T}=380^{\circ} \mathrm{C}, \mathrm{v}=1.0 \mathrm{hr}^{-1}$

\begin{tabular}{|c|c|c|c|}
\hline \multirow{2}{*}{ Name } & \multicolumn{3}{|c|}{ Content of catalyst } \\
\cline { 2 - 4 } & $\mathrm{Pd}, \mathrm{HSHM}$ & $\mathrm{CuFe} \mathrm{O}_{4} \cdot \mathrm{V} \cdot \mathrm{Al}_{2} \mathrm{O}_{3}$ & $\mathrm{~V}_{2} \mathrm{O}_{5} \cdot \mathrm{Cr}_{2} \mathrm{O}_{3} \cdot \mathrm{Al}_{2} \mathrm{O}_{3}$ \\
\hline Conversion of N - methylaniline, \% & 98.5 & 87.0 & 91.5 \\
\hline Selectivity of products, \%, & & & 45.5 \\
\hline 2- methylaniline & 40.0 & 52.5 & 46.0 \\
\hline 3- and 4- methylanilines & 44.0 & 39.5 & 7.5 \\
\hline Dimethylaniline & 5.2 & 6.5 & \\
\hline
\end{tabular}

Table 2. The results of the conversion of $\mathbf{N}-, 2$ - dimethylaniline with different catalysts. Reaction conditions: $\mathrm{T}=380^{\circ} \mathrm{C}, \mathrm{v}=1.0 \mathrm{hr}^{-1}$

\begin{tabular}{|c|c|c|c|}
\hline \multirow{2}{*}{ Name } & \multicolumn{3}{|c|}{ Content of catalyst } \\
\cline { 2 - 4 } & $\mathrm{Pd}, \mathrm{HSHM}$ & $\mathrm{CuFe} \mathrm{O}_{4} \cdot \mathrm{V} \cdot \mathrm{Al}_{2} \mathrm{O}_{3}$ & $\mathrm{~V}_{2} \mathrm{O}_{5} \cdot \mathrm{Cr}_{2} \mathrm{O}_{3} \cdot \mathrm{Al}_{2} \mathrm{O}_{3}$ \\
\hline Conversion of N - methylaniline, \% & 100 & 88.5 & 94.0 \\
\hline Selectivity of products, \%, & & & 48.0 \\
\hline 2.6- dimethylaniline & 38.0 & 53.0 & 47.0 \\
\hline $3.4-, 2.5-$ and 2.3- dimethylanilines & 48.0 & 42.0 & 4.0 \\
\hline Trimethylanilines & 3.5 & 4.5 & \\
\hline
\end{tabular}

Following researches have been conducted in order to determine the main and by conversions in the alkylation reaction of 2 - methylaniline with methanol in the presence of VChA catalyst. Firstly, the role of $\mathrm{N}-, 2-\operatorname{dimethylaniline}$ in the alkylation reaction of 2 - methylaniline with methanol should be determined. That is why, the interaction of $\mathrm{N}-, 2-$ dimethylaniline with VChA catalyst in alkylation reaction has been studied. The results of the conversion of $\mathrm{N}-, 2-$ dimethylaniline with the influence of temperature are shown in Table 3.

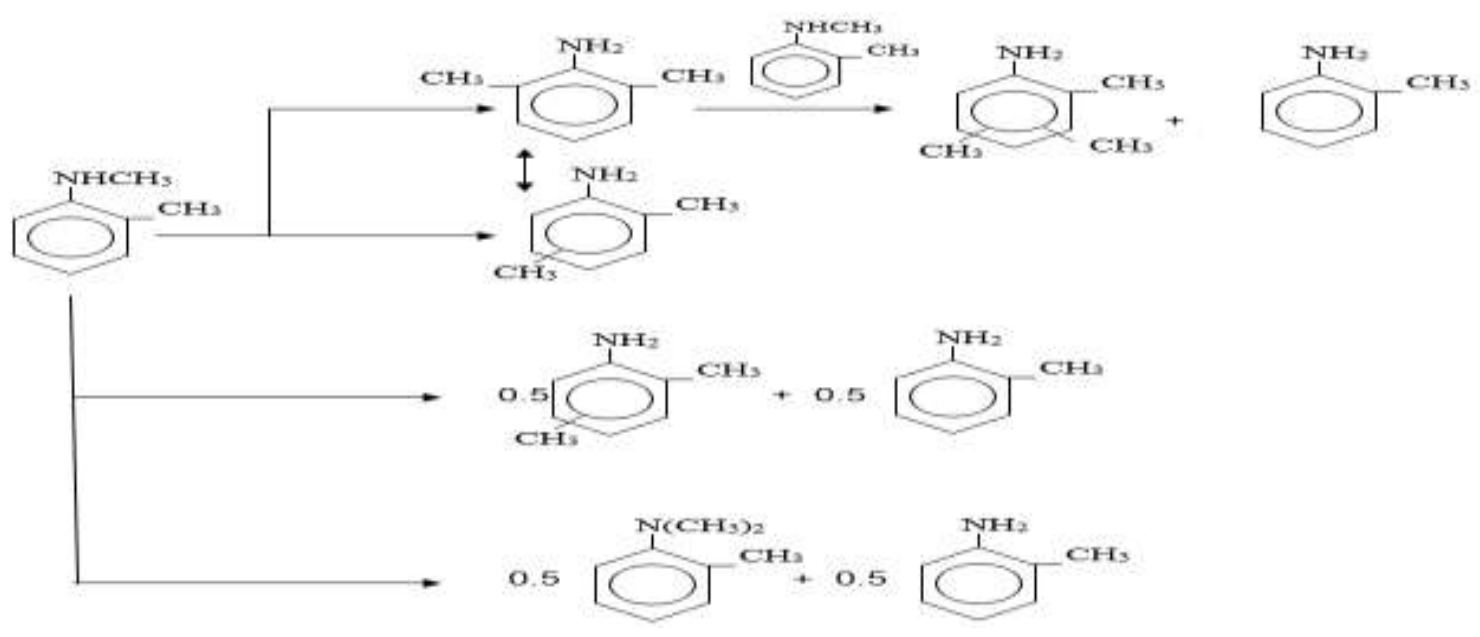


As it is obvious from the results, a number of products are formed as a result of the catalytic conversion of $\mathrm{N}-, 2-$ dimethylaniline. They are 2 - methylaniline, $\mathrm{N}-, \mathrm{N}-, 2$ - trimethylaniline, 2,6 -, 2,4 -, 2,3- and 2,5- dimethylanilines and trimethylanilines. The formation of the mentioned products has been shown by the given reaction scheme.

As it is shown, the mixture of xylidines are formed as a result of the conversion of $\mathrm{N}-, 2$ - dimethylaniline, however $\mathrm{N}-, \mathrm{N}-, 2$ - trimethylaniline is formed due to the same intermolecular conversion and trimethylanilines are formed due to the substitution in nucleus because of different intramolecular interactions during the catalytic cycle.

The rate of the reaction increases due to the increase in temperature. As a result of the analysis of the chemical content of the products, it is clear that the conversion of $\mathrm{N}-, 2$ - dimethylaniline is $100 \%$ at $410^{\circ} \mathrm{C}$ by increasing temperature. In this case, the concentrations of $2-$ methylaniline and $\mathrm{N}-, \mathrm{N}-, 2-$ trimethylaniline increase, whereas the concentration of 2,6 - isomer in xylidine mixture decreases a lot. This change is accompanied by the increase of the concentrations of the other isomers, as well as 2,4-, 2,3-, and 2,5-xylidines.

Table 3. The results of the conversion of $\mathbf{N}-, 2$ - dimethylaniline with VChA catalyst. Reaction condition: $\mathrm{T}=380^{\circ} \mathrm{C}, \mathrm{v}=1.0 \mathrm{hr}^{-1}$

\begin{tabular}{|c|c|c|c|c|}
\hline \multirow[t]{2}{*}{ Name } & \multicolumn{4}{|c|}{ Temperature, ${ }^{\circ} \mathrm{C}$} \\
\hline & 350 & 380 & 410 & $380 *$ \\
\hline \multicolumn{5}{|l|}{$\%$ mass } \\
\hline 2- dimethylaniline & 4.0 & 4.4 & 5.0 & 10.5 \\
\hline $\mathrm{N}-, 2-$ dimethylaniline & 14.0 & 2.4 & - & 11.5 \\
\hline $\mathrm{N}-, \mathrm{N}-$, 2- trimethylaniline & 2.5 & 2.5 & 2.2 & 3.0 \\
\hline 2.6- dimethylaniline & 40.5 & 42.0 & 36.5 & 34.6 \\
\hline 2.4- dimethylaniline & 18.5 & 20.0 & 20.0 & 13.0 \\
\hline 2.5- and 2.3- dimethylanilines & 16.0 & 22.8 & 28.4 & 8.0 \\
\hline Trimethylanilines & 2.5 & 2.9 & 3.3 & 1.5 \\
\hline Unidentified compounds & 1.0 & 1.0 & 1.2 & 1.0 \\
\hline Water & - & - & - & 7.0 \\
\hline Gas and loss & 2.0 & 2.8 & 3.2 & 10.9 \\
\hline Total & 100 & 100 & 100 & 100 \\
\hline
\end{tabular}
dimethylaniline:methanol $=1: 1: 2: \mathrm{mol} / \mathrm{mol} / \mathrm{mol}$ ratio.

As a result of the comparison of the alkylate content which is formed as a result of the alkylation of 2 - methylaniline with methanol at $380^{\circ} \mathrm{C}$ and the product which is formed from the catalytic conversion of $\mathrm{N}-, 2$ - dimethylaniline, a significant difference is observed. Firstly, a huge difference in the content of the produced xylidine mixture draws the attention.

The mass proportion of 2,6 - isomer in the dimethylamine mixture which is produced as a result of the reaction between 2 - methylaniline and methanol is 0.87 , however the same pointer for 2,6 - dimethylaniline in the xylidine mixture which is formed from the conversion of $\mathrm{N}$-,2-dimethylaniline is 0.50 . On the other hand, unlike the alkylation reaction, trimethylaniline mixture is formed as a result of the conversion of $\mathrm{N}$-,2-dimethylaniline and its concentration increases by increasing the temperature.

Figure 1 shows the comparative yields of the products which are formed as a result of thermocatalytic conversion of three different feedstocks by using VChA catalyst.

2 - methylaniline - methanol, $\mathrm{N}-, 2$ - dimethylaniline 2 - methylaniline $-\mathrm{N}, 2$ - dimethylaniline methanol mixture have been taken as a feedstock and selectivity and yields of products according to 2,6 - and other xylidines has been analysed as comparative criterion.

As it is obvious from the results, the yields of converted and calculated according to primary aromatic amine 2,6 dimethylaniline which is formed on the basis of 2 - methylaniline and methanol are $81,4 \%$ and $77.3 \%$, respectively. These pointers are 12.6 and $10.2 \%$ according to the other xylidine mixture respectively. 


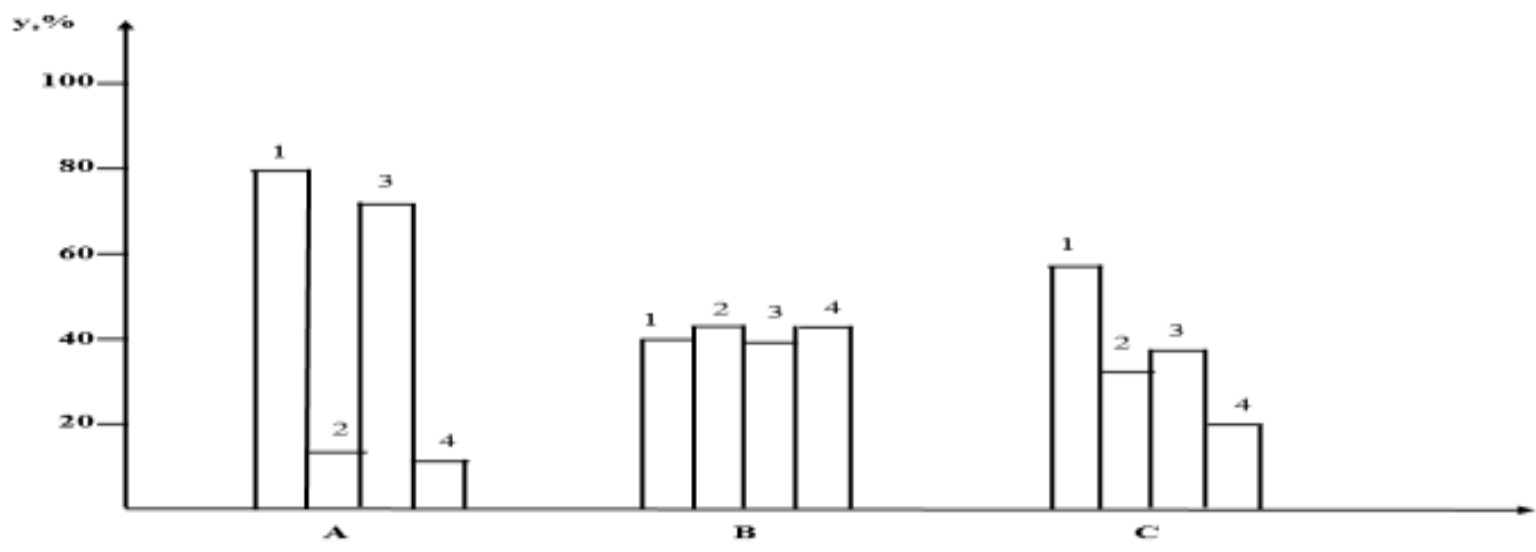

Figure 1: The selectivities and yields of xylidines according to 2,6 - dimethyaniline and other dimethyanilines $(2,4-, 2,5-, 2,3$ - isomers) that are formed from the catalytic conversions of different feedstocks $(A, B, C)$. (3.4) Reaction condition: $\mathrm{T}=\mathrm{T}=380^{\circ} \mathrm{C}, \mathrm{v}=1.0 \mathrm{hr}^{-1}$

The comparison of these data with 2,6 - and the other isomers of xylidine that are formed by the conversion of $\mathrm{N}$ -, 2 - dimethyaniline show a significant difference. The selectivity of 2,6 - isomer which is formed by the catalytic conversion of $\mathrm{N}-, 2$ - dimethyaniline is $37.4 \%$ less, in another word, it is $43.0 \%$, however the selectivity according to other xylidine mixture is $30.2 \%$ higher, in another word, it is $42.8 \%$.

The yields of xylidines that are formed as a result of catalytic conversion of 2 - methylaniline, $\mathrm{N}-2$, dimethylaniline and methanol mixture have a moderate place in comparison to mentioned feedstocks. The selectivity of the reaction according to 2,6 - xylidine is $56.7 \%$, however the formation selectivity of the other xylidines was $34.2 \%$. The yields of these products are $38.3 \%$ and $19.4 \%$, respectively.

\section{CONCLUSION}

These results predict that the partial intermolecular isomerization of $\mathrm{N}-, 2$-dimethylaniline which is formed as a result of reaction of 2 - methylaniline with methanol to xylidines can also occur. However, these results show that the formation of xylidines, especially 2,6 - isomer because of the methylation of aromatic amine due to carbon in nucleus is more real.

\section{REFERENCES}

1. Семиколенов В.А., Малыхин Е-В., Штейнгарц В.Д. Каталитическая технология получения 2.6 диметиланилина и синтез продуктов на его основе // Наука-произ-ву 2004,№5,с.53-55

2. Chen-Li-yu., Zhang Xin Cheng, Dong Wu Izomerization N- methylaniline // Chem. React. Eng and Technol. 2000, 16, ,№2, p.193-197.

3. Pillai R.B. Alkylation of aniline over base /J. Indian. Chem. Soc. 2007,77, №10, c. 490-492.

4. Слепов С.К., Власов С.В Алкилирование анилина спиртами в ядро в присутствии твердых катализаторов //Ж.орг.хим, 1980, №6, с. 1115-1121

5. Агаева А.А., Мустафраева Н.А., Расулов С.Р. Каталитическое взаимодействие 2-метиланилина метанолом// Нефтепереработка и нефтехимия 2013, №3, с.20-22.

6. Aghayev A.A, Mustafayeva N.A., Muradov M.M., Mutallimova K.M. Alkylation of 2-methylaniline with methanol in the presence of zeolite catalysts //Amer. Scientific. Jour. №2 (2), 2016, p 39-42/

7. Aghayev A.A, Mustafayeva N.A., Muradov M.M., Nazarova M.K. Alkylation of 2-methylaniline with the methanol in the presence of eferrite catalysts //Europen. Science Review 2016, №9-10, p 255-258. 